Dokuz Eylül Üniversitesi-Mühendislik Fakültesi

Fen ve Mühendislik Dergisi

Cilt 20, Sayı 58, Ocak, 2018
Dokuz Eylul University-Faculty of Engineering Journal of Science and Engineering Volume 20, Issue 58, January, 2018

DOI: $10.21205 /$ deufmd. 2018205809

\title{
Beton Basınç Dayanım Testlerinde Küçük Ebatlı Küp Beton Numunelerin Yaygın Kullanımı İçin Şekil-Boyut Etkisinin Detaylı İncelenmesi
}

\author{
İrem ŞANAL
}

Bahçeşehir Üniversitesi, Mühendislik ve Doğa Bilimleri Fakültesi, İnşaat Mühendisliği Bölümü, 34349, İstanbul. (ORCID: 0000-0003-1682-1789)

(Alınış / Received: 24.02.2017, Kabul / Accepted: 31.10.2017, Online Yayınlanma / Published Online:20.01.2018)

Anahtar Kelimeler Beton Basınç Dayanımı, Boyut Etkisi, Şekil Etkisi, Kalite Kontrol.
Özet: Bilindiği gibi çeşitli standartlarda basınç dayanım testleri için kabul edilen numune șekil ve boyutları fark gösterebilmektedir. Ancak, zaman ve ekonomik faktörler, zayi olan beton miktarı ve üretilen atığın azalması ve laboratuvarlarda daha düşük kapasiteli beton basınç presi kullanımı göz önünde bulundurulduğunda kalite kontrolünde küçük boyutlarda numune kullanımının daha avantajlı olacağı öngörülmektedir. Bu nedenle, bu çalışma kapsamında, 100 mm'lik küp numune kullanımının pratik uygulamada da arttırllabilmesi için, numune tip ve boyutlarının beton basınç dayanımı üzerindeki etkisinin detaylıca incelenmesi amaçlanmıştır. Bu kapsamda, i) iki farklı kaynaktan alınan, ii) iki farklı karışım içeriğine sahip, iii) dört ayrı beton sınıfına ait, iv) iki ayrı tipte ve v) dört farklı boyuttaki numuneler kullanılarak ölçülen basınç dayanım sonuçları birbirleriyle karşılaştırılmıştır. Böylelikle, basınç deneyinde kullanılan numunelerin şekil ve ebatlarının deneysel sonuçlara olan etkileri geniș kapsamlı olarak değerlendirilmiș ve $100 \mathrm{~mm}$ 'lik küplerin pratikte kullanımının uygunluğu incelenmiştir.

\section{Detailed Evaluation of Size and Shape Effects of Small-Size Cube Samples on Concrete Compressive Strength}

\section{Keywords}

Concrete

Compressive

Strength,

Size Effect,

Shape Effect, Quality Control.
Abstract: As is known, in various standards, the acceptable sample size and dimensions for concrete compressive strength tests may differ. However, considering the time and economic factors, the loss of concrete volume and produced waste, and the possible use of lower capacity concrete compression presses in laboratories, it is foreseen that the use of small sample sizes will be more advantageous in quality control of concrete. Therefore, in this study, it is aimed to investigate the effect of sample shape and size on concrete compressive strength so that the use of $100 \mathrm{~mm}$ cube samples can be increased in practical application. In this context, the results of compressive strength measured for samples from: i) 
İ. Şanal / Beton Basınç Dayanım Testlerinde Küçük Ebatlı Küp Beton Numunelerin Yaygın Kullanımı İçin Şekil-Boyut Etkisinin Detaylı İncelenmesi

two different sources, ii) two different mixtures, iii) four different concrete classes, iv) two different types, and v) four different sizes. Thus, the effects of sample size and shape on the compression test results were extensively evaluated and the suitability of practical use of the $100 \mathrm{~mm}$ cubes were investigated.

*irem ŞANAL, irem.sanal@eng.bau.edu.tr

\section{Giriş}

Beton konusunda yapılan birçok araştırmada, basınç dayanımı en önemli malzeme özelliği olarak kabul edilmektedir. Betonun, diğer birçok özelliğinin basınç dayanımıyla ilişkili olduğu bilinmektedir. Basınç dayanımını etkileyen etkenlerin bașında su-bağlayıcı oranı, agrega, çimento ve kullanılan katkıların kalitesi ile kür şartları ve süresi gelmektedir. Ancak, betonun basınç dayanımını etkileyen diğer önemli bir faktör ise, numune boyut ve şeklinin değișimidir. Çünkü basınç dayanımı, betonun kırılma mekaniklerinden dolayı numune boyut ve șekline bağlı olarak değișmektedir. [1]

Beton kalite kontrolünde yaygın olarak kullanılan ve tek eksenli basınç dayanımı deneyinde de kullanılan örnek tip ve boyutlar, deney sonuçlarını önemli ölçüde etkilemektedir. Bu sorunların üstesinden gelebilmek amaciyla, numune boyut ve șeklinin basınç dayanım değerleri üzerindeki etkisini en aza indirmek ve basınç dayanım değerlerinde bir birlik sağlayabilmek için numune şekil ve boyutlarında bir standartlașmaya gidilmiştir. Bunun sonucunda, beton dayanımının tespitinde kullanılan tek eksenli basınç dayanım deneyinde, standart boyutlarda silindir ve küp numunelerin kullanılması öngörülmüştür. Beton basınç dayanımını ölçmede kullanılan numune boyut ve şekilleri ülkeden ülkeye farklılıklar gösterse de en çok kullanılan numune şekilleri küp ve silindirdir.
Ülkemizin standartlarında yer alan silindir numune boyutları 150x300 mm (Standart silindir numunede, boy/çap=2,0'dır.), küp numune boyutları ise $150 \times 150 \times 150 \mathrm{~mm}^{\prime}$ dir. Ancak, kolay çalışılabilme, iş ve işçi sağlığı, deney aletlerinin kapasitelerinin küçük olması, daha az beton kullanma ve buna bağlı olarak maliyetin daha düşük olması gibi çeşitli sebeplerden dolayı, uygulamalarda standartlarda belirtilen 100x100x100 mm boyutlarındaki numunelerin de kullanılmasının yaygınlaştırılması amaçlanmaktadır. Basınç dayanımı deneyi sonunda elde edilen dayanım değerini etkileyen önemli faktörlerden bazıları aşağıdaki gibi sıralanabilir: [2]

1.Numune şekli ve boyutları, 2.Basınç presi başlığının özellikleri, 3.Deneyde uygulanan yükleme hızı, 4.Kür süresi, koşulları ve deney anında ortamın nemlilik-sıcaklık durumu

5.Numunenin alındığı kaynak ve taşınması

6.Beton karışımı içeriği (mineral katkı, agrega tipi-boyutu, vb)

$\mathrm{Bu}$ çalışmada, yukarıda sözü geçen basınç presi başlık özelliği, yükleme hızı, numunenin kür koșulları, nemliliği ve sicaklığ , agrega tip ve boyutu gibi değișkenler sabit tutularak; numune kaynağının, mineral katkı kullanımının, numune şekil ve boyutunun basınç dayanımına etkileri incelenmiştir. 
İ. Şanal / Beton Basınç Dayanım Testlerinde Küçük Ebatlı Küp Beton Numunelerin Yaygın Kullanımı İçin Şekil-Boyut Etkisinin Detaylı İncelenmesi

\subsection{Numune Kaynağının Beton Basınç Dayanımına Etkisi}

Taze betonun kalitesi numune alınarak belirlenir. $\mathrm{Bu}$ numunelerin, şantiyede dökülen betonun birebir örneği olduğu, onun kalitesini temsil ettiği varsayılır; bu nedenle numune alımı ve korunması, kesinlikle ilgili standartlara uygun olmalıdır. Taze beton numunesi șantiye ya da laboratuvar koşullarında TS EN 12390-2 Standardı'na uygun olarak alınmalı ve saklanmalıdır. Ancak bazen santrallerde üretilen betonun kalitesi elde edilmek istenen betonun kalitesinden farklı olabilmektedir. Bu farklılıklar, karışıma giren malzemenin yapısının değişmesi, santralde karıştırılma süresinin gerekli olandan az veya fazla olması, üretim sonrası beton kıvamı ve teslim sırasındaki beton kıvamının ve sıcaklı̆̆ının farklı olabilmesinden kaynaklanmaktadır. Betona şantiyede yeterli kür yapılmaması durumunda, betonun dayanım kaybına uğrayacağı ve kür havuzunda tutulan numunelerle, dışarıda tutulan numuneler arasında dayanım açısından 3 kata varan farklar oluştuğu saptanmıștır. [3]

Aynı zamanda, santralde numune alınırken, numunenin beton harmanının tamamını homojen bir şekilde temsil etmesine dikkat edilmeli ve yine dayanım açısından farka sebep olacağı için numune, alındıktan hemen sonra taşınmamalı, bekletilmelidir. Çünkü santralde alınan numuneler, rüzgardan ve nem kaybından korunmaz ve taşıma işlemi sırasında, mekanik etkiler (sarsılma vb.),sıcaklık değişimleri ve rutubet kaybından etkilenirse, basınç dayanım sonuçlarında da düşüşler ortaya çıkabilecektir. $\mathrm{Bu}$ nedenle, santral üretimli numune ve laboratuvar ortamında üretilen numunelerin farklılıklarını da göz önünde bulundurmak amacıyla, aynı karışımların hem laboratuvar, hem de santral üretimli numuler teste tabi tutulmuştur.

\subsection{Mineral Katkı Kullanımının Beton Basınç Dayanımına Etkisi}

Uçucu kül betonda mineral katkı olarak kullanılan yapay bir puzolandır ve çoğunlukla kendi başına bağlayıcı olmadığı halde, sönmüş kireçle hidratasyon reaksiyonuna girerek suda sertleşir. Uçucu kül, elektrik üreten termik santrallerden elde edilir ve beton teknolojisinde ya çimento ile birlikte doğrudan betona katılarak, ya da betonda kum yerine kullanılabilirler, böylelikle daha büyük özgül yüzey ve inceliğe sahip olduklarından bağlayıcı hacminin artmasını ve çimentodan ekonomi yapılmasını sağlarlar. Araştırmalar ağırlıkça \% 20 oranında uçucu kül kullanılmasının beton basınç dayanımı açısından olumlu sonuçlar verdiğini göstermiștir [4]. Bunun yanında uçucu kül kullanılması ile betonun erken yaştaki basınç ve eğilme dayanımları düşmekte $[5,6]$, prizi geciktirmektedir [7].

Uçucu kül ile yapılan bir çalışmada [4] $\% 20$ uçucu kül kullanıldığında kontrol betonuna yakın basınç dayanımları elde edilmiş ve uçucu kül ile birlikte akışkanlaştırıcı da kullanıldığında birim ağırlıklarda azalma meydana gelmiş, akışkanlaştırıcı kullanılmadığında birim ağırlıklar artmıștır. Ayrıca yüksek dayanımlı betonlarda çimento yerine $\%$ 25 oranında uçucu kül kullanılması ile basınç dayanımları ve elastisite modülleri düşmekte, çekme ve eğilme dayanımları artmaktadır. Uçucu kül kullanımının beton basınç dayanımını azalttığı ve miktarının artırılması durumunda dayanımın daha da geç kazanıldığı anlașılmıștır. 
İ. Şanal / Beton Basınç Dayanım Testlerinde Küçük Ebatlı Küp Beton Numunelerin Yaygın Kullanımı İçin Şekil-Boyut Etkisinin Detaylı İncelenmesi

Yapılan başka bir çalışmada ise uçucu külün, çimento üretimi sırasında \% 7.5 oranında kullanılmasının betonun mekanik özeliklerini olumlu yönde etkilediği belirtilmektedir [8].

Dolayısıyla bu çalışma kapsamında, uçucu külün beton basınç dayanımı üzerindeki etkilerini detaylıca görebilmek için, farklı kür sürelerine tabi tutulmuş, farklı beton sınıfında, boyut ve şekilleri farklı olan numunelerin beton basınç dayanımları karşılaştırılacaktır.

\subsection{Numune Şeklinin Beton Basınç Dayanımına Etkisi}

Numune şekli ve boyutları basınç dayanım sonuçlarını doğrudan etkilemekte ve genel olarak küp numunelerin basınç dayanımı silindir numunelerden yüksek olmaktadır. Bunun nedenleri: i) silindir numunede gerilme yoğunluğunun daha uniform dağılması ve küp numunede gerilme yoğunluğunun köșelerde daha fazla olması, ii) yükleme makinası ile numune arasındaki sürtünme kuvvetinin küp numunede daha etkili olması, iii) kırım ve beton döküm yönlerinin farklı olması, ve iv) agrega gradasyonunun küp numune dayanımını silindir numuneden daha çok etkilemesi gibi nedenlerle açıklanabilir. [9]

Buradaki en önemli etken numunelerin geometrik şekiller sonucu oluşan gerilme etki alanlarının farklı olmasıdır. Numune yüzeyi ve basınç makinası başlığı arasındaki sürtünmeden dolayı numunede yatay gerilme oluşur. Bu yatay gerilme basınç dayanımını arttırıcı çok eksenli gerilme etkisi meydana getirir. Konik veya piramit şeklindeki bir alanda bu etki meydana gelir. Şekil 1'de görüleceği gibi küp numune tamamen bu etki altındadır, ancak silindir numunede bu etkinin meydana gelmediği bir bölge mevcuttur.

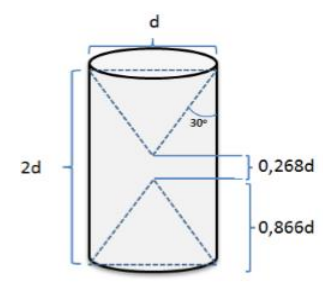

(a)

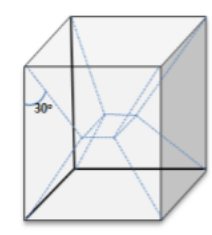

(b)

Şekil 1. Çok eksenli gerilmenin a)silindir ve b) küp numunede etki alanları [10].

\subsection{Numune Boyutlarının Beton Basınç Dayanımına Etkisi}

Boyut etkisi göz önünde bulundurulduğunda ise, numunelerin boyutu küçüldükçe basınç dayanımının artmakta olduğu bilinmektedir. $\mathrm{Bu}$ durumu en iyi izah edecek durum hacim arttıkça betondaki kusur ve zayıflıkların daha çok ve daha belirgin olmasıdır. Numune boyutlarının büyümesi, istatiksel olarak, numunede bulunabilecek mikro çatlakların veya diğer hatalı bölümlerin miktarını da artırmaktadır. O nedenle, daha küçük boyutlu numuneler üzerinde yapılan deneylerde, daha yüksek basınç dayanımı değerleri elde edilmektedir [11].

Özdemir [12], numune şekil ve boyutunun yüksek dayanımlı betonun basınç mukavemeti üzerindeki etkisini araștırmıștır. Basınç dayanım değerleri 40, 60 ve $75 \mathrm{MPa}$ olan üç değişik mukavemet düzeyinde çalışmalar 
İ. Şanal / Beton Basınç Dayanım Testlerinde Küçük Ebatlı Küp Beton Numunelerin Yaygın Kullanımı İçin Şekil-Boyut Etkisinin Detaylı İncelenmesi

yapmıştır. Araştırmacl, küçük boyutlu ve küçük boy/çap oranına sahip olan numunelerin basınç dayanımında daha iyi sonuçlar gösterdiklerini belirtmektedir. Boy/çap oranlarının yüksek dayanımlı betonların basınç dayanımı üzerindeki etkisini incelendiğinde, boy/çap oranı 1,00 olan numunelerin en iyi performansı gösterdiği ve boy/çap oranı azaldıkça, dayanım değerinin arttığı gözlenmektedir. Çopuroğlu [13], betonun dayanım seviyesi ve numunenin şekil ve boyut değişiminin basınç ve yarmada çekme dayanımları üzerindeki etkisini incelemiştir. Araştırmada, farklı S/B oranlarında hazırlanan $7,5 \times 15,10 \times 20$ ve $15 \times 30 \mathrm{~cm}$ boyutlarındaki silindirlerle, 10,15 ve 20 $\mathrm{cm}$ boyutlarındaki küp numunelerin tahribatlı ve tahribatsız yöntemlerle 7 ve 28 günlük dayanımları test edilmiștir. Araştırma sonucunda, standart olarak kullanılmakta olan $15 \mathrm{~cm}^{\prime}$ lik küp numuneler ile $15 \times 30 \mathrm{~cm}$ boyutlarındaki silindir numunelerin basınç dayanımları arasında 0,74 ile 0,94 arasında değişen bir oran bulunmuştur. Genel eğilim, dayanım seviyesi arttıkça, bu oranın küçüldüğü yönündedir. Küp numunelerde boyut etkisi kuralına uygun olarak numune boyutu büyüdükçe, dayanımların azaldığı görülmüştür. Ancak silindir numunelerde bunun tam tersi bir durumla karşılaşılmıştır. Araştırmacı bu durumun sebebini, çeper etkisi ve başlık yapımındaki güçlüklere bağlamaktadır.

\subsection{Beton Dayanım Sınıfının Basınç Dayanım Sonuçlarına Etkisi}

Felekoğlu ve Türkel [2], farklı boyutlarda küp ve silindir formdaki numunelerin basınç dayanım değerlerini iki farklı dayanım sınıfı için incelemişler ve bu boyutlar arasında geçiş katsayıları önermişlerdir. Elde edilen bulgular ışığında, numuneler arasındaki geçiş katsayılarının beton dayanım sınıfına göre değişkenlik gösterdiği belirlenmiştir. Çalışmada, küçük boyutlu numuneler kullanıldığında, elde edilen dayanımların ve sonuçlardaki değişkenliğin arttığı belirtilmektedir.

\subsection{Küçük Boyutlu Numunelerin Basınç Dayanım Testinde Kullanılması} \begin{tabular}{lccr} 
Basınç & dayanımı & \multicolumn{2}{c}{ deneylerinde } \\
kullanılan & beton & numunelerin \\
boyutunun & küçük & olması bazı \\
avantajlara & sebep olmaktadır. & Bu \\
avantajlar: & (i) & küçük boyutlu
\end{tabular} numunelerin daha kolay kaldırılabilir ve taşınabilir olması, (ii) numuneler için kullanılan kalıplar da küçük olduğundan maliyetlerin daha düşük olması, (iii) daha az miktarda beton kullanılması sonucu, zayi olan beton miktarının ve atığın azalması (iv) küçük boyutlu numunelerin kesit alanları ve dolayısıyla kırılma yükleri de daha küçük olduğundan, daha düşük kapasiteli makinelerde deneye tabi tutulabilmeleri ve (v) numunelerin hazırlanması için daha az beton, kür işlemleri için daha az alan gerekli olması gibi sıralanabilir. Öte yandan, örnek numunelerin boyutunun küçük kullanılmasının getirdiği bazı dezavantajlar da olabilmektedir, örneğin numunelerin boyutunun küçük olması, dayanımların göreceli olarak artmasına neden olup, deney sonuçları arasında değişkenliği artırarak, karşılaștırma yapılmasını güçleştirebilmektedir.

TS EN 206 Standardı [14] $150 \mathrm{~mm}$ kenar ebatlı küp ve 150/300 mm ebadinda silindir numunelerin kullanılmasına izin vermis; ancak farklı ebatlar için de açık kapı bırakmıştır. 2015 yllında yayınlanan bir genelge ile $100 / 200 \mathrm{~mm}$ ebadında silindir numune 
İ. Şanal / Beton Basınç Dayanım Testlerinde Küçük Ebatlı Küp Beton Numunelerin Yaygın Kullanımı İçin Şekil-Boyut Etkisinin Detaylı İncelenmesi

alınmasının da önü açılmıştır. 100 mm'lik küp numune kullanımı ise birçok avantajları olmasına ve standartlar açısından kullanımının mümkün olmasına rağmen pratik uygulamada ne yazık ki yer almamaktadır.

$\mathrm{Bu}$ nedenle, bu çalışmada, 100 mm'lik küp numune kullanımının pratik uygulamada da arttırılabilmesi için, numune tip ve boyutlarinın beton basınç dayanımı üzerindeki etkisinin detaylı olarak incelenmesi amaçlanmıştır. Küçük numunelerle elde edilen dayanımların ve sonuçlardaki değişkenliğinin inceleneceği bu çalışma kapsamında, i) iki farklı kaynaktan alınan (beton üretim tesisi ve laboratuvar), ii) iki farklı karışım içeriğine sahip (mineral katkılı veya mineral katkısız), iii) dört ayrı beton sınıfına ait (C30, C35, C50 ve C70), iv) iki ayrı tipte (küp ve silindir) ve v)dört farklı boyuttaki numuneler $(10 \mathrm{~cm}$ ve $15 \mathrm{~cm}$ 'lik küpler, $10 \times 20 \mathrm{~cm}$ ve $15 \times 30 \mathrm{~cm}$ 'lik silindirler) kullanılarak ölçülen basınç dayanım sonuçları birbirleriyle karşılaştırılmıştır.

\section{Materyal ve Metot}

Beton karışımlarında kullanılan malzemeler, karıșım oranları ve deneysel çalışmalarda kullanılan yöntemler bu bölümde sunulmuştur.

\subsection{Kullanılan Malzemeler}

Hem laboratuvarda yapilan deneysel çalışmalar süresince, hem de santralden temin edilen numuneler için kullanılan malzemeler ve özellikleri aşağıda belirtilmiștir.

\subsubsection{Agrega}

Çalışmaların tamamında aynı kaynaktan ve aynı kırma eleme tesisinden elde edilen kırmakum (0-4mm), kırmataş

No1(4-11,2 mm) ve No2 (11,2-22,4 $\mathrm{mm})$ agregaları kullanılmıştır. Kullanılan agregaların fiziksel özellikleri ve karışım tane boyut dağılımı, Tablo 1 ve Şekil 2'de verilmiştir.

Tablo 1. Beton dizaynında kullanılan agregaların fiziksel özellikleri ve karışım oranları

\begin{tabular}{|c|c|c|}
\hline Deney Adı & $\begin{array}{l}\text { Numune } \\
\text { Tanımı }\end{array}$ & Sonuç \\
\hline \multirow{3}{*}{$\begin{array}{l}\text { Tane Yoğunluğu } \\
\text { (Yüzey Kuru Suya } \\
\text { Doygun) }\end{array}$} & $\begin{array}{l}\text { Kırma } \\
\text { Kum }\end{array}$ & $\begin{array}{l}2,65 \\
\mathrm{Mg} / \mathrm{m} 3\end{array}$ \\
\hline & $\begin{array}{l}\text { Agrega } \\
\text { No1 }\end{array}$ & $\begin{array}{l}2,66 \\
\mathrm{Mg} / \mathrm{m} 3\end{array}$ \\
\hline & $\begin{array}{l}\text { Agrega } \\
\text { No2 }\end{array}$ & $\begin{array}{l}2,68 \\
\mathrm{Mg} / \mathrm{m} 3\end{array}$ \\
\hline \multirow[t]{3}{*}{ Su Emme Oranı } & $\begin{array}{l}\text { Kırma } \\
\text { Kum }\end{array}$ & $1,40 \%$ \\
\hline & $\begin{array}{l}\text { Agrega } \\
\text { No1 }\end{array}$ & $0,70 \%$ \\
\hline & $\begin{array}{l}\text { Agrega } \\
\text { No2 }\end{array}$ & $0,60 \%$ \\
\hline \multirow[t]{2}{*}{ Yassılık endeksi } & $\begin{array}{l}\text { Agrega } \\
\text { No1 }\end{array}$ & $4 \%$ \\
\hline & $\begin{array}{l}\text { Agrega } \\
\text { No2 }\end{array}$ & $2 \%$ \\
\hline \multirow{2}{*}{$\begin{array}{l}\text { İri agregaların } \\
\text { parçalanmaya karşı } \\
\text { direnci-Los Angeles }\end{array}$} & $\begin{array}{l}\text { Agrega } \\
\text { No1 }\end{array}$ & \multirow[t]{2}{*}{$20 \%$} \\
\hline & $\begin{array}{l}\text { Agrega } \\
\text { No2 }\end{array}$ & \\
\hline $\begin{array}{l}\text { Çok ince malzeme } \\
\text { muhtevası }(0,063 \\
\text { mm geçen) }\end{array}$ & $\begin{array}{l}\text { Kırma } \\
\text { Kum }\end{array}$ & $11,60 \%$ \\
\hline
\end{tabular}

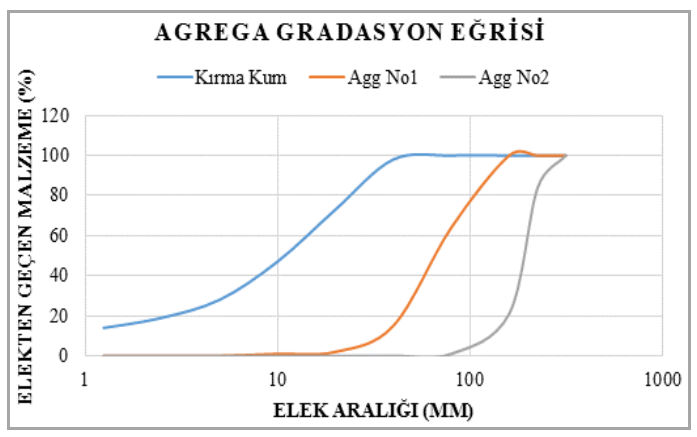


İ. Şanal / Beton Basınç Dayanım Testlerinde Küçük Ebatlı Küp Beton Numunelerin Yaygın Kullanımı İçin Şekil-Boyut Etkisinin Detaylı İncelenmesi

Şekil 2. Kullanılan agregaların tane boyut dağılımı

\subsection{2. Çimento}

Deneysel çalışmada CEM I 42.5 tipi çimento kullanılmıştır. Kullanılan çimentonun üretici firmadan alınan fiziksel ve kimyasal özellikleri Tablo 2'de verilmiştir.

Tablo 2. Deneysel çalışmada kullanılan CEM I 42,5R çimentonun kimyasal ve fiziksel özellikleri

\begin{tabular}{|c|c|}
\hline Özellikler & $\begin{array}{l}\text { CEM I } \\
42,5 R\end{array}$ \\
\hline Kızdırma Kaybı (\%) & 1,67 \\
\hline $\mathrm{SO}_{3}(\%)$ & 2,724 \\
\hline $\mathrm{Cl}(\%)$ & 0,008 \\
\hline Çözünmeyen Kalıntı (\%) & 1,04 \\
\hline $\begin{array}{l}2 \text { Günlük Basınç Dayanımı } \\
(\mathrm{MPa})\end{array}$ & 27,3 \\
\hline $\begin{array}{c}7 \text { Günlük Basınç Dayanımı } \\
(\mathrm{MPa})\end{array}$ & 42,5 \\
\hline $\begin{array}{l}28 \text { Günlük Basınç Dayanımı } \\
(\mathrm{MPa})\end{array}$ & 57,3 \\
\hline Priz Başlangıcı (dk) & 150 \\
\hline Priz Sonu (dk) & 215 \\
\hline Hacim Genleşmesi (mm) & 1 \\
\hline Yoğunluk (gr/cm³) & 3,12 \\
\hline Özgül Yüzey $\left(\mathrm{cm}^{2} / \mathrm{gr}\right)$ & 3950 \\
\hline
\end{tabular}

\subsubsection{Uçucu Kül}

Tunçbilek Uçucu külü için EN 450-1 Standardına [15] göre yapılmış olan kimyasal ve fiziksel analiz sonuçları Tablo 3'de verilmiştir.

Tablo 3. Tunçbilek uçucu külünün kimyasal özellikleri

\begin{tabular}{|c|c|}
\hline KIMYASAL DENEYLER ( $\%)$ \\
\hline $\mathbf{S i O}_{\mathbf{2}}$ & 56,3 \\
\hline $\mathbf{A l}_{2} \mathbf{O}_{3}$ & 20,7 \\
\hline $\mathbf{F e}_{2} \mathbf{O}_{3}$ & 10 \\
\hline $\mathbf{C a O}$ & 3,52 \\
\hline $\mathbf{M g O}$ & 3,24 \\
\hline $\mathbf{N a} \mathbf{O}$ & 0,376 \\
\hline $\mathbf{K}_{2} \mathbf{O}$ & 1,95 \\
\hline
\end{tabular}

\begin{tabular}{|c|c|}
\hline $\mathrm{SO}_{3}$ & 1,74 \\
\hline Klorür $\left(\mathrm{Cl}^{-}\right)$ & 0,0078 \\
\hline
\end{tabular}

\subsubsection{Akıșkanlaștıcı Kimyasal Katkı}

Deneysel çalışma programında dört farklı dayanım sınıfında beton üretimi yapılmış olup, su kesme amaciyla akışkanlaştırıcı kimyasal katkı kullanılmıștır. Söz konusu katkı C30 ve C35'de Glenium 150; C50 beton sinıfinda Glenium 3561; C70 da ise Glenium 608'dir.

\subsection{Deney Yöntemi ve Karışım Oranları}

Deneysel çalıșmada basınç dayanım testine tabi tutulacak numuneler 2 farklı boyutta $(10 \mathrm{~cm} \mathrm{x} 20 \mathrm{~cm}$ ve $15 \mathrm{~cm} \mathrm{x} 30 \mathrm{~cm})$ silindir ve 2 farkl boyutta $(10 \mathrm{~cm}$ $\mathrm{x} 10 \mathrm{~cm}$ ve $15 \mathrm{~cm} \times 15 \mathrm{~cm}$ ) küp numuneler olarak belirlenmiștir.

Beton karıșım oranları, OYAK Beton'un standart reçetelerine göre, çökme değeri $15( \pm 3) \quad \mathrm{cm}$ olacak şekilde belirlenmiş ve C30, C35, C50 ve C70 sınıfı betonlar için hazırlanmıştır. Deneysel çalışmada numune boyut ve şekil değișkenlerine ek olarak, bu 4 farklı dayanım sınıfında hem mineral katkısız, hem de mineral (uçucu kül) katkılı beton üretimi hedeflenmiştir. Beton karışım bileşenlerinin detayları Tablo 4'te sunulmuştur.

Ancak bazen santrallerde üretilen betonun kalitesi elde edilmek istenen betonun kalitesinden farklı olabilmektedir. Bu farklılıklar, karışıma giren malzemenin yapısının değişmesi, santralde karıștırılma süresinin gerekli olandan az veya fazla olması, üretim sonrası beton kıvamı ve teslim sırasındaki beton kivamının ve sıcaklığının farklı olabilmesinden kaynaklanmaktadır. Bu nedenle, santral üretimli numune ve laboratuvar 
İ. Şanal / Beton Basınç Dayanım Testlerinde Küçük Ebatlı Küp Beton Numunelerin Yaygın Kullanımı İçin Şekil-Boyut Etkisinin Detaylı İncelenmesi

ortaminda üretilen numunelerin farklılıklarını da göz önünde bulundurmak amaciyla, aynı karıșımların hem laboratuvar, hem de santral üretimli numuler teste tabi tutulmuştur.

Tablo 4. Deneysel Çalışmada Kullanılan Beton Karışım Oranları

\begin{tabular}{|c|c|c|c|c|c|}
\hline \multirow{2}{*}{ MALZEMELER } & \multirow{2}{*}{ Tip } & \multicolumn{4}{|c|}{ Mineral Katkısız } \\
\hline & & C30 & C35 & C50 & $\mathrm{C70}$ \\
\hline$w / c$ oranı & - & 0,65 & 0,60 & 0,45 & 0,38 \\
\hline$w / b$ oranı & - & 0,64 & 0,59 & 0,44 & 0,37 \\
\hline Serbest Su Miktarı & $\mathrm{kg} / \mathrm{m}^{3}$ & 166,0 & 165,0 & 159,0 & 163,0 \\
\hline Teorik Hava Miktarı & $\%$ & $2,0 \%$ & $2,0 \%$ & $2,0 \%$ & $2,0 \%$ \\
\hline Kıvam Sınıfı & Çökme & $15+-3$ & $15+-3$ & $15+-3$ & $15+-3$ \\
\hline \multirow{2}{*}{ MALZEMELER } & \multirow{2}{*}{ TiP } & \multicolumn{4}{|c|}{ Mineral Katkılı } \\
\hline & & сзо & C35 & C50 & C70 \\
\hline w/c oranı & - & 0,65 & 0,60 & 0,45 & 0,38 \\
\hline$w / b$ oranı & - & 0,64 & 0,59 & 0,44 & 0,37 \\
\hline Serbest Su Miktarı & $\mathrm{kg} / \mathrm{m}^{3}$ & 166,0 & 165,0 & 159,0 & 163,0 \\
\hline Teorik Hava Miktarı & $\%$ & $2,0 \%$ & $2,0 \%$ & $2,0 \%$ & $2,0 \%$ \\
\hline Kıvam Sınıfı & Çökme & $15+-3$ & $15+-3$ & $15+-3$ & $15+-3$ \\
\hline
\end{tabular}

Beton basınç dayanımının elde edilmesi Standart deney yöntemi TS EN 123903:2010 verilmektedir. Standart deney yönteminin uygulamasinda, beton standartlarında belirtilen standart silindir veya küp numuneler kullanılmaktadır. Beton numune bu kalıplara yerleştirilmekte ve bir gün sonra kalıptan çıkarılmaktadır. Bu numuneler daha sonra standartta belirtilen yöntem uygulanarak 28 günlük küre tabi tutulmakta ve kırılım gününde deney presi vasitasıla üniform basınç yükü altında kırılmaktadır. Üretilen numunelerin tamamina TS EN 12390-2 standardına uygun olarak su kürü uygulanmıştır. İzlenen isıl işlem programında numuneler 28 gün süreyle $20 \pm 2^{\circ} C^{\prime}$ de kirece doygun su içinde saklanmıştır.

\section{Bulgular}

Deneysel çalıșmaya kapsamındaki tüm numunelerin aynı yükleme ve ortam koşullarında elde edilen ortalama (3 numuneden) basınç dayanımları Tablo 5'te verilmiștir.

\subsection{Numune Kaynağının Basınç Dayanımına Etkisi}

Tablo 5'teki basınç dayanım sonuçlarından da görüleceği gibi, santralden alınan beton numunelerin basınç dayanımları, C70 sınıfı numuneler hariç, laboratuvar numunelerine göre çoğunlukla düşük dayanım göstermiştir.

Santral numunelerinin basınç dayanımındaki düşüşü daha iyi gözlemleyebilmek adına, Tablo 6 ve Şekil 3'te beton sınıflarına göre, santral ve laboratuvar numuneleri arasındaki basınç dayanımının yüzdesel değişimi verilmiştir.

Tablo 6 ve Şekil 3'te de görüleceği gibi, C30-35 sinıfı normal dayanımlı betonlarda, santralden alınan numunelerin beton basınç dayanımları, labortauar ortamında dökülen numunelerin beton basıncından düşük çıkmıştır. Yalnızca, C70 sınıfı şantiyeden alınan numunelerin basınç dayanımları, laboratuarda dökülen numunelerin basınç dayanımından yüksek çıkmıştır.

Santral numunelerinin basınç dayanım sonuçlarının laboratuar numunelerine kıyasla, kürün hemen başlatılamaması, santralden numunelerin taşınma süresi, şantiye ortamında kalıpların durumu, ve benzeri gibi sebepler düşünüldüğünde düşük çıkması beklenen bir durumdur. 
İ. Şanal / Beton Basınç Dayanım Testlerinde Küçük Ebatlı Küp Beton Numunelerin Yaygın Kullanımı İçin Şekil-Boyut Etkisinin Detaylı İncelenmesi

Tablo 5. Basınç Dayanım Sonuçları

\begin{tabular}{|c|c|c|c|c|c|c|c|}
\hline & & \multirow{3}{*}{ (4) } & \multirow{3}{*}{$\begin{array}{l}\text { Beton } \\
\text { Sinifi }\end{array}$} & \multicolumn{4}{|c|}{$\begin{array}{c}\text { Ortalama Beton } \\
\text { Basınc Dayanımı }\end{array}$} \\
\hline & & & & \multicolumn{4}{|c|}{2 günlük } \\
\hline & & & & K10 & K15 & S10 & S15 \\
\hline \multirow{16}{*}{ 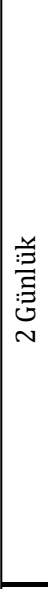 } & \multirow{8}{*}{ 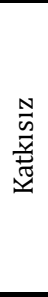 } & \multirow{4}{*}{$\pi$} & 30 & 14 & 11 & 11 & 10 \\
\hline & & & C35 & 24 & 4 & 23 & 28 \\
\hline & & & $\begin{array}{l}\mathrm{C} 50 \\
\end{array}$ & 45 & 45 & 43 & 40 \\
\hline & & & $\begin{array}{l}\mathrm{C} 70 \\
\end{array}$ & 33 & 32 & 29 & 27 \\
\hline & & & C30 & 8 & 7 & 7 & 6 \\
\hline & & & $\mathrm{C} 35$ & 22 & 22 & 21 & 21 \\
\hline & & & C50 & 18 & 19 & 17 & 16 \\
\hline & & & $\begin{array}{l}\mathrm{C} 70 \\
\end{array}$ & 51 & 50 & 45 & 46 \\
\hline & \multirow{8}{*}{ 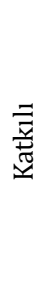 } & & $\overline{\mathrm{C} 30}$ & 10 & 9 & 9 & 9 \\
\hline & & & C35 & 31 & 29 & 27 & 27 \\
\hline & & & C50 & 45 & 44 & 45 & 43 \\
\hline & & & $\mathrm{C70}$ & 52 & 49 & 4 & 50 \\
\hline & & \multirow{4}{*}{ 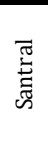 } & C30 & 6 & 6 & 6 & 5 \\
\hline & & & C35 & 23 & 22 & 22 & 20 \\
\hline & & & C50 & 20 & 21 & 17 & 16 \\
\hline & & & C70 & 41 & 39 & 33 & 35 \\
\hline \multirow{16}{*}{ : } & & \multirow{4}{*}{$\sqrt{\pi}$} & C30 & 46 & 43 & 39 & 37 \\
\hline & & & C35 & 42 & 41 & 41 & 45 \\
\hline & & & C50 & 65 & 6. & 59 & 62 \\
\hline & & & C70 & 70 & 6 & 59 & 68 \\
\hline & & \multirow{4}{*}{$\mathrm{E}$} & C30 & 32 & 31 & 28 & 29 \\
\hline & & & C35 & 39 & 3 & 35 & 35 \\
\hline & & & C50 & 49 & 46 & 45 & 43 \\
\hline & & & $\mathrm{C} 70$ & 78 & 64 & 69 & 68 \\
\hline & \multirow{8}{*}{ 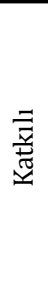 } & \multirow{4}{*}{$\vec{\sigma}$} & C30 & 37 & 4 & 37 & 36 \\
\hline & & & C35 & 44 & 41 & 40 & 39 \\
\hline & & & $\begin{array}{l}\mathrm{C} 50 \\
\end{array}$ & 65 & 64 & 61 & 60 \\
\hline & & & $\begin{array}{l}\text { C70 } \\
\end{array}$ & 67 & 62 & 65 & 67 \\
\hline & & \multirow{4}{*}{ 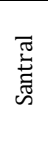 } & C30 & 23 & 25 & 23 & 23 \\
\hline & & & C35 & 40 & 38 & 36 & 36 \\
\hline & & & $\begin{array}{l}\mathrm{C} 50 \\
\end{array}$ & 51 & 4 & 4 & 44 \\
\hline & & & $\begin{array}{l}\text { C70 } \\
\end{array}$ & 69 & 65 & 56 & 58 \\
\hline & & & C30 & 50 & 49 & 43 & 42 \\
\hline & & (요 & C35 & 49 & 50 & 48 & 51 \\
\hline & & $\stackrel{9}{9}$ & C50 & 74 & 69 & 66 & 68 \\
\hline & $\vec{n}$ & & $\begin{array}{l}\text { C70 } \\
\end{array}$ & 79 & 70 & 71 & 74 \\
\hline & $\mp$ & & C30 & 38 & 37 & 35 & 34 \\
\hline & & שू & C35 & 48 & 46 & 45 & 45 \\
\hline & & $\pi$ & C50 & 56 & 5 & 5 & 47 \\
\hline & & & $\begin{array}{l}\mathrm{C} 70 \\
\end{array}$ & 91 & 82 & 76 & 76 \\
\hline & & & C30 & 46 & 43 & 44 & 44 \\
\hline & & $\approx$ & C35 & 54 & 47 & 47 & 49 \\
\hline & & 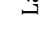 & C50 & 77 & 72 & 68 & 66 \\
\hline & $\overline{\bar{x}}$ & & $\begin{array}{l}\mathrm{C} 70 \\
\end{array}$ & 79 & 75 & 79 & 79 \\
\hline & 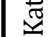 & & C30 & 35 & 33 & 30 & 31 \\
\hline & & $\pi$ & C35 & 45 & 46 & 43 & 43 \\
\hline & & & C50 & 59 & 54 & 51 & 46 \\
\hline & & & C70 & 81 & 74 & 67 & 72 \\
\hline
\end{tabular}

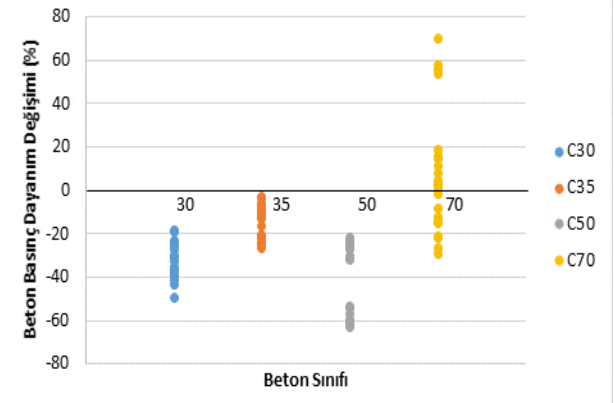

Şekil 3. Beton sınıflarına göre, santral ve laboratuvar numuneleri arasindaki basınç dayanımındaki yüzdesel değişim

Ancak, yüksek dayanımlı C70 sınıfı numunelerde, santral numunelerinin daha yüksek basınç dayanım sonucu vermesi, diğer faktörlerle birlikte de incelenip açılanması gereken bir konudur.

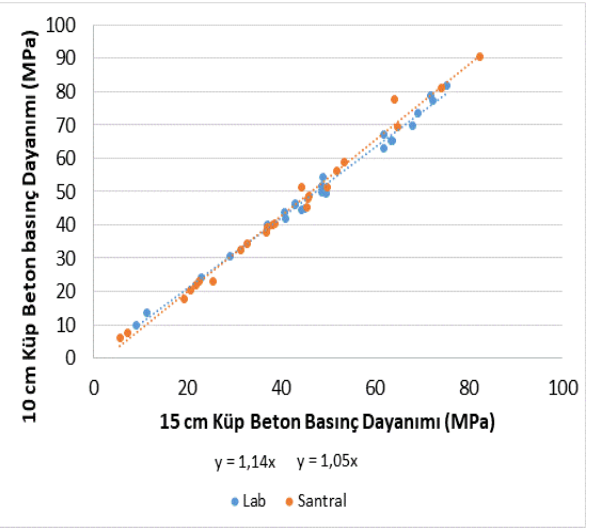

Şekil 4. Küp numunelerin beton basınç dayanımlarının kaynak etkisine göre karşılaștırılması

$10 \mathrm{~cm}$ ebatlı ve $15 \mathrm{~cm}$ ebatlı küp numunelerin beton basinç dayanımlarının kaynak etkisine göre karşılaştırılmasının verildiği Şekil 4, detaylıca incelendiğinde numunenin alındığı kaynağın, farklı boyutlardaki küp numune basınç dayanımı arasındaki 
İ. Şanal / Beton Basınç Dayanım Testlerinde Küçük Ebatlı Küp Beton Numunelerin Yaygın Kullanımı İçin Şekil-Boyut Etkisinin Detaylı İncelenmesi

ilişki ve dönüşüm katsayısı üzerinde belirgin bir etkisi olmadığı

günlük), \%16 civarında bir artışa neden olurken, 7 günlük ve 28 günlük test sonuçlarında bu etki oldukça azalmış ve

Tablo 6. Santral ve laboratuvar numuneleri basınç dayanımındaki yüzdesel değişim

\begin{tabular}{|c|c|c|c|c|c|c|c|c|c|c|c|c|c|c|c|c|c|c|c|c|c|c|c|c|}
\hline \multirow{4}{*}{$\begin{array}{c}\text { Beton } \\
\text { Sinifi }\end{array}$} & \multicolumn{24}{|c|}{ Santral Numuneleri Beton Basınç Dayanımındaki Değişim (\%) } \\
\hline & \multicolumn{12}{|c|}{ Katkısız } & \multicolumn{12}{|c|}{ Katkılı } \\
\hline & \multicolumn{4}{|c|}{2 günlük } & \multicolumn{4}{|c|}{7 günlük } & \multicolumn{4}{|c|}{28 günlük } & \multicolumn{4}{|c|}{2 günlük } & \multicolumn{4}{|c|}{7 günlük } & \multicolumn{4}{|c|}{28 günlük } \\
\hline & K10 & K15 & S10 & S15 & K10 & K15 & S10 & S15 & K10 & K15 & S10 & S15 & K10 & K15 & S10 & S15 & K10 & K15 & S10 & S15 & K10 & K15 & S10 & S15 \\
\hline C30 & -44 & -35 & -41 & -33 & -30 & -27 & -27 & -23 & -25 & -24 & -19 & -19 & -39 & -38 & -39 & -49 & -38 & -36 & -37 & -36 & -25 & -24 & -31 & -31 \\
\hline $\mathrm{C} 35$ & -8 & -11 & -9 & -26 & -6 & \begin{tabular}{|l|}
-10 \\
\end{tabular} & -13 & -21 & -3 & -8 & -6 & -12 & -24 & -23 & -20 & -24 & -9 & \begin{tabular}{|l|}
-7 \\
\end{tabular} & -9 & -6 & \begin{tabular}{|l|}
-17 \\
\end{tabular} & -4 & -10 & -12 \\
\hline $\mathrm{C50}$ & \begin{tabular}{|l|}
-61 \\
\end{tabular} & -57 & -62 & -60 & -25 & \begin{tabular}{|l|}
-27 \\
\end{tabular} & -24 & -30 & -24 & -25 & -25 & -32 & -54 & -54 & \begin{tabular}{|l|}
-63 \\
\end{tabular} & -62 & -22 & -30 & -26 & -27 & -24 & -26 & -25 & -31 \\
\hline $\mathrm{C} 70$ & 54 & 58 & 56 & 70 & 11 & 2 & 16 & 0 & 15 & \begin{tabular}{|l|}
18 \\
\end{tabular} & 8 & 3 & -22 & -21 & -26 & -30 & 3 & 5 & -14 & -12 & 3 & -1 & -15 & -9 \\
\hline
\end{tabular}

Tablo 7. Mineral katkılı ve katkısız numunelerin ortalama arasındaki dayanım sonuçları

\begin{tabular}{|c|c|c|c|c|c|c|c|c|c|c|c|c|c|c|c|c|c|c|c|c|c|c|c|c|c|c|}
\hline \multirow{4}{*}{ t* } & & \multirow{4}{*}{$\begin{array}{c}\text { Beton } \\
\text { Sinifi }\end{array}$} & \multicolumn{24}{|c|}{ Ortalama Beton Basınç Dayanımı (MPa) } \\
\hline & & & \multicolumn{4}{|c|}{2 günlük } & \multicolumn{4}{|c|}{7 günlük } & \multicolumn{4}{|c|}{28 günlük } & \multicolumn{4}{|c|}{2 günlük } & \multicolumn{4}{|c|}{7 günlük } & \multicolumn{4}{|c|}{28 günlük } \\
\hline & & & K10 & K15 & S10 & S15 & K10 & K15 & S10 & S15 & K10 & K15 & s10 & S15 & K10 & K15 & S10 & S15 & K10 & K15 & S10 & S15 & K10 & K15 & S10 & S15 \\
\hline & & & \multicolumn{12}{|c|}{ KatkıSIz } & \multicolumn{12}{|c|}{ Katkılı } \\
\hline & \multirow{4}{*}{$\infty^{\circ}$} & $\mathrm{C} 30$ & 14 & 11 & 11 & 10 & 46 & 43 & 39 & 37 & 50 & 49 & 43 & 42 & 10 & 9 & 9 & 9 & 37 & 40 & 37 & 36 & 46 & 43 & 44 & 44 \\
\hline & & C35 & 24 & 24 & 23 & 28 & 42 & 41 & 41 & 45 & 49 & 50 & 48 & 51 & 31 & 29 & 27 & 27 & 44 & 41 & 40 & \begin{tabular}{|l|}
39 \\
\end{tabular} & 54 & 47 & 47 & 49 \\
\hline & & C50 & 45 & 45 & 43 & 40 & 65 & 63 & 59 & 62 & 74 & 69 & 66 & 68 & 45 & 44 & 45 & 43 & 65 & 64 & 61 & 60 & 77 & 72 & 68 & 66 \\
\hline & & C70 & 33 & 32 & 29 & 27 & 70 & 63 & 59 & 68 & 79 & 70 & 71 & 74 & 52 & 49 & 45 & 50 & 67 & 62 & 65 & 67 & 79 & 75 & 79 & 79 \\
\hline & \multirow{4}{*}{$\cos _{0} x^{2}$} & C30 & 8 & 7 & 7 & 6 & 32 & 31 & 28 & 29 & 38 & 37 & 35 & 34 & 6 & 6 & 6 & 5 & 23 & 25 & 23 & 23 & 35 & 33 & 30 & 31 \\
\hline & & C35 & 22 & 22 & 21 & 21 & 39 & 37 & 35 & 35 & 48 & 46 & 45 & 45 & 23 & 22 & 22 & 20 & 40 & 38 & 36 & 36 & 45 & 46 & 43 & 43 \\
\hline & & C50 & 18 & 19 & 17 & 16 & 49 & 46 & 45 & 43 & 56 & 52 & 50 & 47 & 20 & 21 & 17 & 16 & 51 & 44 & 45 & 44 & 59 & 54 & 51 & 46 \\
\hline & & C70 & 51 & 50 & 45 & 46 & 78 & 64 & 69 & 68 & 91 & 82 & 76 & 76 & 41 & 39 & 33 & 35 & 69 & 65 & 56 & 58 & 81 & 74 & 67 & 72 \\
\hline
\end{tabular}

görülmektedir.

\subsection{Mineral Katkı Kullanımının Basınç Dayanımına Etkisi}

Mineral katkı kullanımının beton basınç dayanımına etkisi Tablo 7 ve Şekil 5'de detaylıca verilmiștir. Tablo 7 detaylı olarak incelendiğinde, mineral katkı kullanılan numunelerin 2 günlük basınç dayanımlarında düşüş gözlenirken, kür süresi 2 günden 28 güne çıktığında numunelerin büyük çoğunluğu için basınç dayanımlarında olumsuz bir etki olmadığı görülmüștür. Dolayısıyla mineral katkılı betonlarda beklenen bir sonuç olan, erken yaşlarda basınç dayanımında düşüş gözlenirken, ileriki yaşlarda basınç dayanımı üzerinde fazla bir değişim gözlenmemektedir. C50 sınıfı betonlarda mineral katkının beton basınç dayanımı üzerinde etkisi neredeyse hiç yoktur. C25 sınıfı betonlarda mineral katkının beton basınç dayanımına etkisi erken yaşta (2 kaybolmuştur. Şekil 5a ve 5b'deki genel eğilime bakıldığında ise, $10 \mathrm{~cm}$ ve $15 \mathrm{~cm}$ ebatlı küp ve silindir numunelerin basınç dayanım sonuçları arasındaki ilişki, mineral katkı kullanımından oldukça az etkilenmiştir.

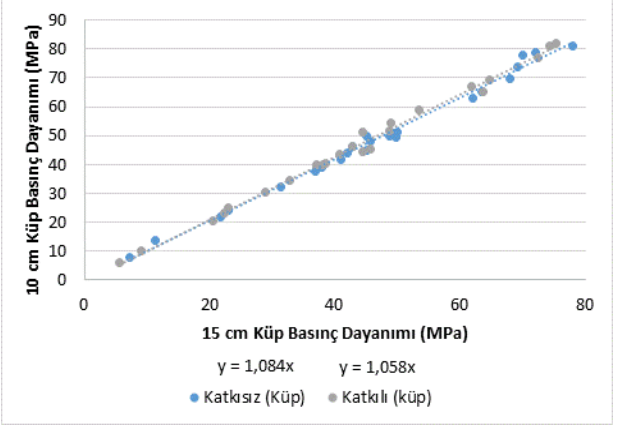


İ. Şanal / Beton Basınç Dayanım Testlerinde Küçük Ebatlı Küp Beton Numunelerin Yaygın Kullanımı İçin Şekil-Boyut Etkisinin Detaylı İncelenmesi

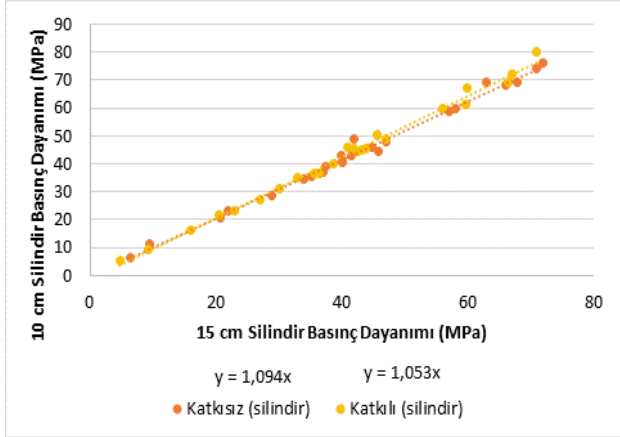

Şekil $5.10 \mathrm{~cm}$ ebatlı ve $15 \mathrm{~cm}$ ebatlı a) küp ve b) silindir numunelerin beton basınç dayanımlarının mineral katkı etkisine göre karşılaştırılması

\subsection{Numune Boyutunun Basınç Dayanımına Etkisi}

Aynı betondan üretilen değişik boyuttaki numunelerin basınç dayanımları, boyut etkisinden dolayı farklı olabilmektedir. Tablo 7 'de 15 mm'lik küp ve silindir numunelerin beton basınç dayanım sonuçları 10mm'lik numunelerle karşılaştırılmış ve sonuçları yüzde değişim olarak verilmiştir.

Tablo 7. $15 \mathrm{~mm}$ ebatlı küp ve silindir numunelerin beton basınç dayanımındaki yüzdesel değișim

\begin{tabular}{|c|c|c|c|c|c|c|c|c|}
\hline \multirow{3}{*}{$+20^{+\infty}$} & \multirow{3}{*}{$+200^{\circ}$} & \multirow{3}{*}{$\begin{array}{l}\text { Beton } \\
\text { Sinif! }\end{array}$} & \multicolumn{6}{|c|}{ Beton Basınç Dayanımı Azalış (\%) } \\
\hline & & & \multicolumn{2}{|c|}{2 günlük } & \multicolumn{2}{|c|}{7 günlük } & \multicolumn{2}{|c|}{28 günlük } \\
\hline & & & Küp & Silindir & Küp & Silindir & Küp & Silindir \\
\hline \multirow{8}{*}{ 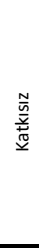 } & \multirow{4}{*}{$2^{\circ}$} & $\mathrm{C} 30$ & -16 & -14 & -8 & -4 & -2 & -3 \\
\hline & & C35 & 2 & 25 & -2 & 10 & 1 & 6 \\
\hline & & C50 & 0 & -7 & -3 & 5 & -6 & 4 \\
\hline & & C70 & -5 & -6 & -10 & 14 & -12 & 5 \\
\hline & & $\mathrm{C} 30$ & -4 & -2 & -3 & 1 & -2 & -2 \\
\hline & & $\mathrm{C} 35$ & -1 & 1 & -6 & -1 & -5 & -1 \\
\hline & & $\mathrm{C50}$ & 10 & -3 & -6 & -4 & -8 & -6 \\
\hline & & $\mathrm{C} 70$ & $\begin{array}{l}-3 \\
\end{array}$ & 3 & -18 & -2 & \begin{tabular}{|l|}
-9 \\
\end{tabular} & 0 \\
\hline \multirow{8}{*}{ 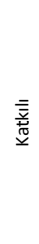 } & \multirow{4}{*}{$0^{\circ}$} & C30 & -9 & 1 & 6 & -2 & -7 & 0 \\
\hline & & C35 & -5 & -1 & -7 & -3 & -13 & 4 \\
\hline & & $\mathrm{C50}$ & 0 & -5 & -3 & -3 & -6 & -2 \\
\hline & & $\mathrm{C} 70$ & -5 & 10 & -8 & 3 & -5 & -1 \\
\hline & \multirow{4}{*}{$5^{0<0^{20}}$} & C30 & $\begin{array}{l}-7 \\
\end{array}$ & -16 & 9 & \begin{tabular}{|c|}
-1 \\
\end{tabular} & -5 & 1 \\
\hline & & C35 & -3 & -6 & -5 & 0 & 0 & 1 \\
\hline & & C50 & 1 & -3 & -13 & -3 & -9 & -10 \\
\hline & & $\mathrm{C} 70$ & -5 & 5 & -6 & 4 & -8 & 7 \\
\hline
\end{tabular}

Numunelerin beton basınç dayanım sonuçlarından da görülebileceği üzere, (15 mm'lik) büyük boyutlu numunelerin sonuçlarında çoğunlukla azalma olduğu farkedilmiştir. Büyük boyutlu numunelerin beton basınç dayanımlarının küçük boyutlu numunelere göre düşük çlkması, literatürüdeki önceki çalışmalar ve numunedeki kusur bulunma olasılığının artışı göz önünde bulundurulduğunda, beklenen bir sonuçtur.

Şekil 6'dan da görüldüğü üzere, küp numunelerde $15 \mathrm{~cm}$ ebatl numune ve $10 \mathrm{~cm}$ ebatlı numune arasındaki dönüşüm katsayısı oldukça yüksek bir korelasyonla 1,05 çıkmış olup, bu değer silindir numuneler için yine çok yüksek bir korelasyonla 0,98dayan hem küp, hem de silindir numuneler için boyut arttıkça, beton basınç dayanımı azalmaktadır. $\mathrm{Bu}$ durumun oluşma nedenleri beton numunelerin alt ve üst yüzeyleri ile deney presinin başlıklarının yüzeyleri arasındaki sürtünme nedeniyle numunelerin uçlarına yakın kısımlardaki kayma kuvvetinin etkisi numunenin kesit alanına göre farklı olmasıdır. Küçük boyutlu numunelerde bu yüzey, büyük numunelere kıyasla küçüktür.

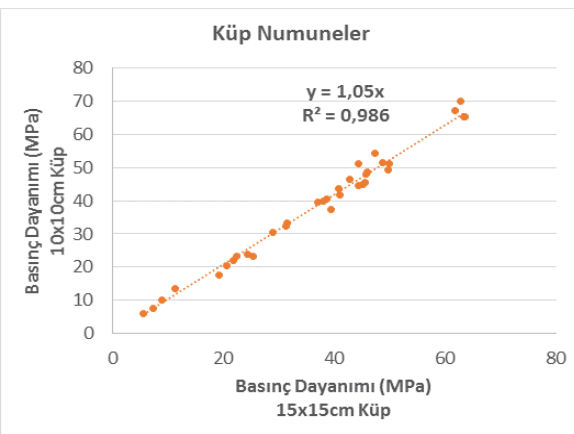


İ. Şanal / Beton Basınç Dayanım Testlerinde Küçük Ebatlı Küp Beton Numunelerin Yaygın Kullanımı İçin Şekil-Boyut Etkisinin Detaylı İncelenmesi

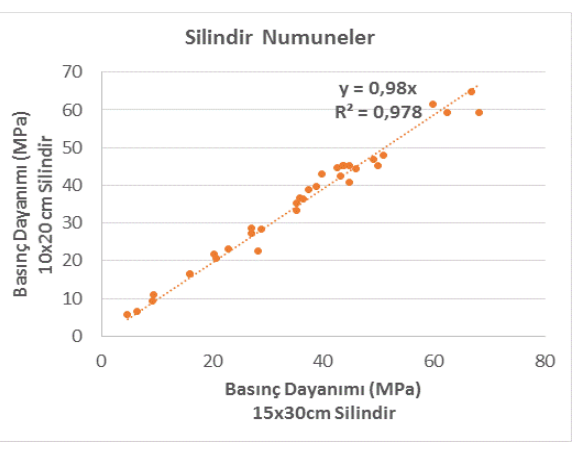

Şekil 6. a) Küp ve b) silindir numunelerin beton basınç dayanımlarının boyut etkisine göre karşılaştırılması

Ancak, başlıca neden, küçük boyutlu numunelerin kesit alanları ve hacimlerinin küçük olması ve bulunan kusur oranının azalmasından kaynaklanmaktadır. Numune boyutlarının büyümesi, istatistiksel olarak numunede bulunabilecek mikro çatlakların veya diğer hatalı bölümlerin miktarını da artırmaktadır. Bu nedenle, küçük numuneler üzerinde yapılan deneylerde daha yüksek dayanım elde edilmektedir.

Lessard ve ark. (1993), çeșitli beton numuneler üzerinde gerçekleştirdikleri deneylerde, $100 \times 200 \mathrm{~mm}$ boyutlu silindir ile $150 \times 300 \mathrm{~mm}$ boyutundaki silindirlerin basınç dayanımları arasında 1,05 gibi bir oran saptamışlardır.

\subsection{Numune Şeklinin Basınç Dayanımına Etkisi}

Küp numuneler üzerinde elde edilen basınç dayanımı değeri, silindir numuneden elde edilen basınç dayanımından yüksektir. Değişik dayanımlara sahip betonlar kullanılarak araştırılan $15 \times 30 \mathrm{~cm}$ boyutlu silindirlerle, $15 \mathrm{~cm}$ boyutlu küpler ve $10 \times 20 \mathrm{~cm}$ boyutlu silindirlerle, $10 \mathrm{~cm}$ boyutlu küpler arasındaki ilişki Şekil 7 ve Tablo 8'de detaylı olarak verilmiștir.

Deney sonuçlarına göre, hem $10 \mathrm{~cm}$, hem de $15 \mathrm{~cm}$ kenar uzunluğu olan küp numunelerde, silindir numunelere göre daha yüksek dayanım elde edilmiştir. Silindir basınç dayanımı ve küp basınç dayanımı arasında dönüșüm katsayısı olarak 10 cm'lik numuneler için, 1.094 bulunurken; $15 \mathrm{~cm}$ 'lik numuneler için 1.022 bulunmuştur.

Bunun bașlica sebeplerinden biri silindir numunelerde yükleme başlığıyla temas eden yüzeyin zayıf olmasıdır. Silindir kalıplara yerleştirilen beton numune, sertleștikten sonra bu eksende kırılmaktadır, fakat küp kalıba dikey eksende yerleștirilen beton, sertleştikten sonra 90 derece çevrilerek kırılmaktadır.
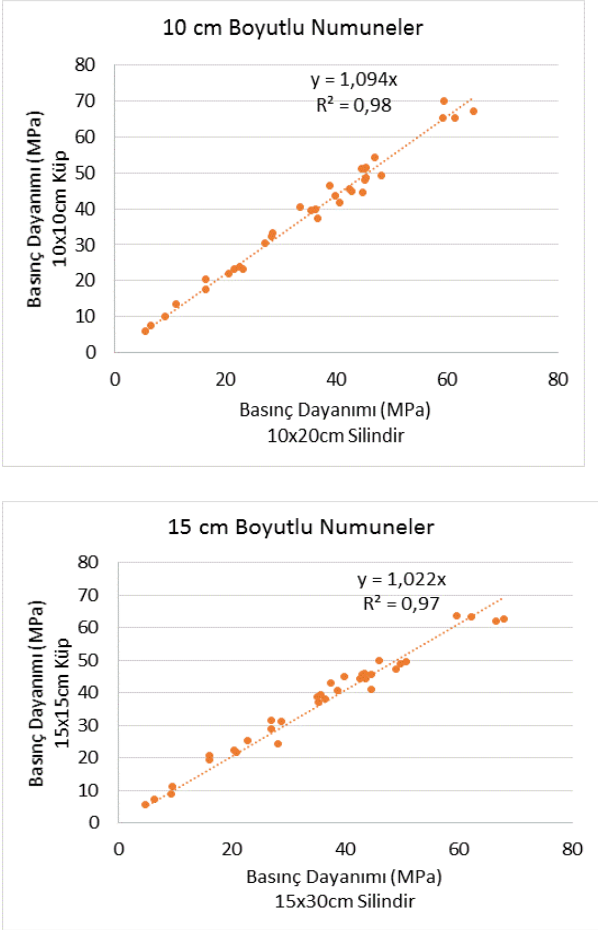

Şekil 7. a) $10 \mathrm{~cm}$ ebatlı ve b) $15 \mathrm{~cm}$ ebatlı küp ve silindir numunelerin beton 
İ. Şanal / Beton Basınç Dayanım Testlerinde Küçük Ebatlı Küp Beton Numunelerin Yaygın Kullanımı İçin Şekil-Boyut Etkisinin Detaylı İncelenmesi

basınç dayanımlarının şekil etkisine göre karşılaştırılması

Silindir numunelerin bu nedenle üst kısmı terlemeden dolayı daha gözenekli ve zayıf bir yapıya sahiptir. Küp numunede böyle bir durum söz konusu değildir. $\mathrm{Bu}$ nedenle de küp numunelerin basınç dayanımlarının silindir numunelerden yüksek olması beklenen bir durumdur.

Şekil 7 daha detaylı incelendiğinde ve bulunan silindir-küp basınç dayanımı dönüşüm katsayıları da göz önünde bulundurulduğunda, silindir basınç dayanımı ile küp basınç dayanımı arasındaki farkın, küçük boyutlu betonlarda daha fazla olduğu görülmektedir. Küp numunelerin basınç dayanımının, silindir numunelerin basınç dayanımından daha fazla olmasının nedenleri boy/çap oranı 2 olan silindir numunelerin alt ve üst uçlarına yakın kısımları kayma kuvvetleri etkisinde bulunurken, numune ortalarına doğru kayma kuvvetinin etkisi ortadan kalkmasıyla açıllanabilir. Küp numunelerde ise, boy/genişlik oranı 1 dir. $\mathrm{Bu}$ nedenle, kayma kuvvetlerinin etkisinden kurtulamamaktadır.

Tablo 8. Silindir numunelerin beton basınç dayanımındaki yüzdesel değişim

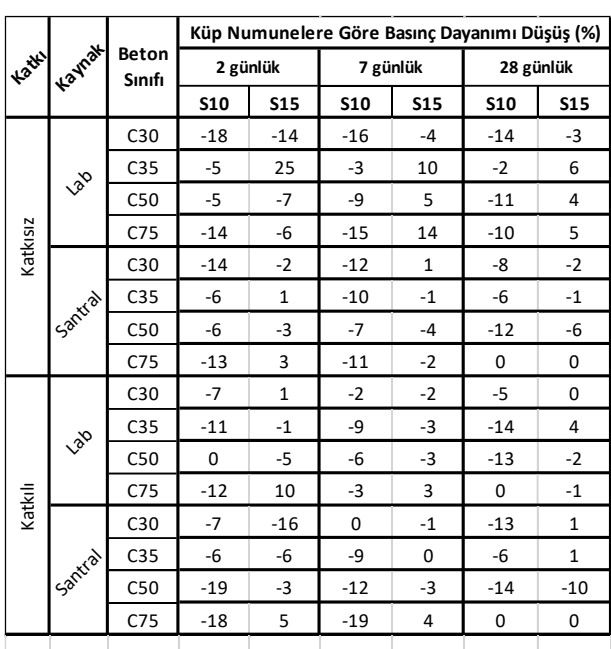

\begin{tabular}{|l|c|c|c|c|c|c|}
\hline Toplam Düşüş & -161 & -17 & -145 & 15 & -127 & -3 \\
\hline
\end{tabular}

Tablo 8 incelendiğinde de yine silindir numunelerdeki basınç dayanım düşüşlerinin $10 \mathrm{~cm}$ 'lik (ufak boyutlu) numunelerde daha belirgin bir fark yarattığı görülmüştür. $\mathrm{Bu}$ sonuç, silindir-küp basınç dayanım dönüşümleri için bulunmuş olan katsayılarla da tutarlıdır. Bir başka deyişle, küçük boyutlu numunelerde küp ve silindir beton basınç dayanım farkl, daha büyük boyuttaki numunelere göre fazla olmaktadır. Yani numune boyutu küçüldükçe, silindir-küp beton basınç dayanımı arasındaki fark artmaktadır.

Ayrıca yine, Tablo 8 incelendiğinde küp ve silindir numune dayanımları arasındaki değişim yüzdelerinden, beton dayanım sınıfı arttıkça aradaki farkın genelde azaldığı görülmektedir. Yapılan çalışmalarda ve literatürde yer alan makalelerde de C50 ve üzeri beton sinıflarında küp ve silindir numune arasındaki dayanım farkının standardın belirttiği değerlerden daha az olduğu tespit edilmiştir.

\subsection{Numune Yaşının Beton Basınç} Dayanımına Etkisi 
İ. Şanal / Beton Basınç Dayanım Testlerinde Küçük Ebatlı Küp Beton Numunelerin Yaygın Kullanımı İçin Şekil-Boyut Etkisinin Detaylı İncelenmesi

Beton dayanımını etkileyen öenmli faktörlerden biri de betonun yaşıdır. Beton basınç testleri standarda uygun olarak, 28 günlük dayanımları ölçmek üzere uygulanır, çünkü 28 günden sonraki dayanım artışı çok azdır. Deneysel çalışma kapsamında, numune yaşının beton boyutlarına bağlı bir etkisi olup olmadığının detaylıca incelenmesi için, erken basınç dayanımlarının da ölçülüp karşılaştırılması düşünülmüş ve beton numunelerin 2 günlük, 7 günlük ve 28 günlük basınç dayanım değerleri ölçülmüştür. $10 \mathrm{~cm}$ ve $15 \mathrm{~cm}$ ebatlı numuneler için, dayanım kazanım değerleri nihai dayanıma göre yüzdesel olarak hesaplanmış ve aralarındaki ilişki Şekil 8'de detaylıca verilmiştir.

Şekil 8a ve 8b'den de görüleceği üzere, daha küçük boyutlu olan $10 \mathrm{~cm}$ ebatlı küp numuneler, C30 ve C35 sinıfi numuneler için, hem 2 günlük hem de 7 günlük dayanım sonuçlarında daha yüksek sonuç vermişlerdir. Dolayısıyla C30 ve C35 sınıfi betonlarda, küçük boyutlu numunelerin dayanım kazanımının, büyük boyutlu numunelere göre daha hızlı olduğu sonucu görülmüştür. C50 sınıfı numuneler için 2 ve 7 günlük dayanım kazanımlarında ise, $10 \mathrm{~cm}$ ve $15 \mathrm{~cm}$ ebatlı numunelerin basınç dayanım kazanımlarında numune boyutunun etkisi neredeyse hiç görülmemiştir. Ancak, C70 sınıfı numunelerin sonuçları incelendiğinde, bu kez büyük boyutlu olan $15 \mathrm{~cm}$ ebatlı küp numunelerin, hem 2, hem de 7 günlük sonuçlarında küçük boyutlu numunelere göre az da olsa daha fazla dayanım kazandığı görülmüştür.

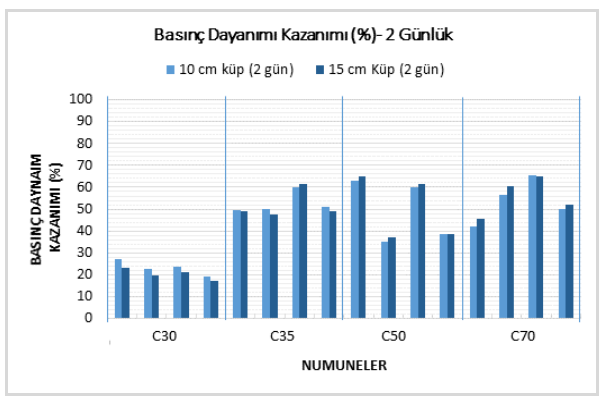

(a)

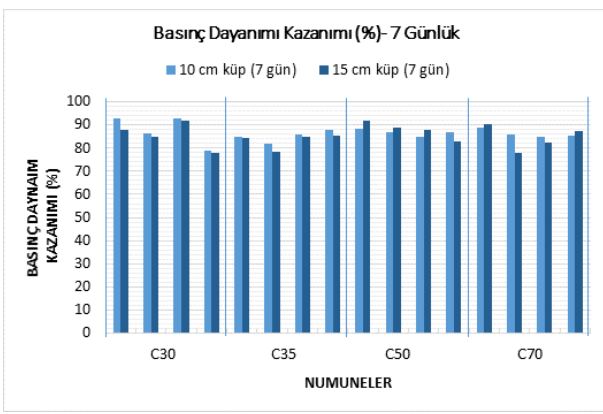

(b)

Şekil 8. $10 \mathrm{~cm}$ ve $15 \mathrm{~cm}$ ebatlı küp numunelerin 28 günlük basınç dayanımlarına göre, dayanım kazanım yüzdeleri a) 2 günlük kür süresi, b) 7 günlük kür süresi

Deneysel çalışma sonucu ölçülen bu değerler, beklendiği gibi daha küçük boyutlu numunelerin, daha büyük boyutlu numunelere göre daha hızlı kurumakta olup, daha hızlı dayanım kazanması sonucuyla örtüşmektedir. 0 nedenle, ilk günlerde, deneye tabi tutulan numunelerde, daha küçük boyutlu olanlar, daha yüksek dayanım göstermektedir. Bu etki düşük sınıftaki betonlar için (C30 ve C35) daha fazla görülmektedir. Betonun yaşı, ilerledikçe, değişik boyutlu numuneler arasındaki dayanım farkı azalmakta, dolayısıyla numune boyut etkisi de gözlenmemektedir. 
İ. Şanal / Beton Basınç Dayanım Testlerinde Küçük Ebatlı Küp Beton Numunelerin Yaygın Kullanımı İçin Şekil-Boyut Etkisinin Detaylı İncelenmesi

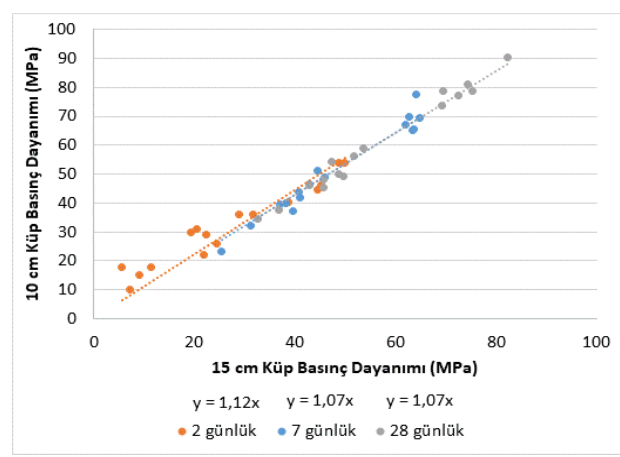

Şekil 9. $10 \mathrm{~cm}$ ebatlı ve $15 \mathrm{~cm}$ ebatlı a) küp numunelerin beton basınç dayanımlarının beton yaşına göre karşılaştırılması

$10 \mathrm{~cm}$ ve $15 \mathrm{~cm}$ ebatlı küp ve silindir numunelerin basınç dayanım sonuçları arasındaki ilişki, erken dayanım değerleri için (2 günlük) küçük boyutlu numunelerde, büyük boyutlu numunelere göre daha yüksek olup, aralarındaki fark 1,12 dönüşüm katsayısı ile daha fazla iken, 7 ve 28 günlük dayanım sonuçlarında, küçük boyutlu numunelerin basınç dayanımı büyük boyutlu numunelere göre daha az artış göstermekte, dönüşüm katsayısı 1,07'ye inmekte ve basınç dayanım kazanım yüzdesi üzerinde numune boyutunun etkisi azalmaktadır.

\subsubsection{Farklı Beton Sınıfının Basınç Dayanımına Etklisi}

Araștırma sonucunda, standart olarak kullanılmakta olan $15 \mathrm{~cm}$ ' lik küp numuneler ile 10 cm'lik küp numunelerin basınç dayanımları arasında lineer bir ilişki bulunmuştur; ancak bu ilişkinin farklı beton sınıflarına göre nasıl bir değișim gösterdiği ise daha detaylı olarak Şekil 10'da verilmiştir.

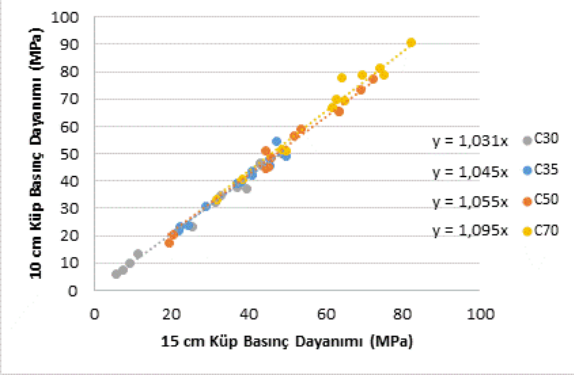

Şekil 10. $10 \mathrm{~cm}$ ebatlı ve $15 \mathrm{~cm}$ ebatlı küp numunelerin beton basınç dayanımlarının beton sınıflarına göre karşılaştırılması

Şekil 10'da görüldüğü üzere, $15 \mathrm{~cm}$ ebatl küp numunelerin basınç dayanımlarının $10 \mathrm{~cm}$ ebatlı küp numune basınç dayanımlarıyla ilişkilendirilmesi için bulunmuş olan katsayılar 1,031 ile 1,095 arasında değişen bir oran bulunmuştur. Genel eğilim, dayanım sınıfı arttıkça, bu oranın arttığı yönündedir. Dolayısıyla, yüksek dayanım sınıfında küçük boyutlu numuneler kullanıldığında, elde edilen dayanım sonuçlarının artmasıyla birlikte, numune boyutuna bağlı olan dayanım ilişkisindeki değişkenliğin arttı̆̆ da söylenebilir.

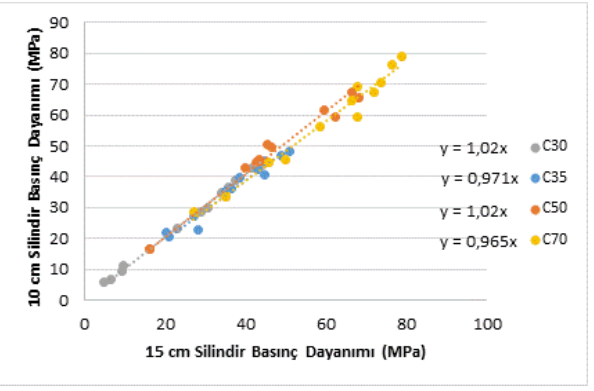

Şekil $11.10 \mathrm{~cm}$ ebatlı ve $15 \mathrm{~cm}$ ebatlı silindir numunelerin beton basınç dayanımlarının beton sınıflarına göre karşılaştırılması

Şekil 11'de görüldüğü üzere, $15 \mathrm{~cm}$ ebatlı silindir numunelerin basınç dayanımlarının $10 \mathrm{~cm}$ ebatlı silindir numune basınç dayanımlarıyla ilişkilendirilmesi için bulunmuş olan 
İ. Şanal / Beton Basınç Dayanım Testlerinde Küçük Ebatlı Küp Beton Numunelerin Yaygın Kullanımı İçin Şekil-Boyut Etkisinin Detaylı İncelenmesi

katsayılar 0,965 ile 1,02 arasinda değişen bir oran bulunmuştur. Silindir numunelerin basınç dayanımı söz konusu olduğunda, küp numuneler için olduğu gibi genel bir eğilimden bahsetmek mümkün olmayacaktır; ancak silindir numunelerde beton sınıfındaki değișimin numune boyutuna göre dayanım ilişkisindeki değişkenliğe belirgin bir etkisi olmadığı söylenebilir.

\section{Tartışma ve Sonuç}

Küçük boyutlu beton numunelerin kullanımının artması için beton basınç dayanımlarının değişkenliğinin detaylıca incelendiği bu çalışma kapsamında, farklı kaynaktan alınan (beton üretim tesisi ve laboratuvar), mineral katkılı ve mineral katkısı), farklı beton sinıfına ait, farklı boyutlardaki küp ve silindir numuneler kullanılarak ölçülen basınç dayanım sonuçları birbirleriyle karşılaştırılmıştır.

Çalışma sonucunda, numunenin alındığı kaynağın, farklı boyutlardaki küp numune basınç dayanımı arasındaki ilişki ve dönüşüm katsayısı üzerinde belirgin bir etkisi olmadığ görülmektedir. Mineral katkı kullanımının ise, nihai basınç dayanımları üzerinde özellikle erken yaşlarda düşüş gözlenirken, ileriki yaşlarda basınç dayanımı üzerinde fazla bir değişim yaratmadığı gözlenmiştir. Bununla birlikte $10 \mathrm{~cm}$ ve $15 \mathrm{~cm}$ ebatl küp ve silindir numunelerin basınç dayanım sonuçları arasındaki ilişki ve dönüşüm katsayıları, mineral katkı kullanımından da oldukça az etkilenmiştir.

Küp numuneler üzerinde elde edilen basınç dayanım sonuçları ise, beklendiği gibi silindir numunelerinkinden yüksek çıkmakta olup, silindir ve küp basınç dayanımı arasındaki fark, yüksek dayanımlı betonlarda daha fazla olmaktadır.

Çalışma sonucunda, farklı boyutta numuneler üzerinde ölçülen basınç dayanım değerleri arasında yüksek korelasyon katsayılı doğrusal ilişki bulunduğu saptanmış olup, numune boyutu küçüldükçe, literatüre uygun olarak, betonun basınç dayanımının arttığı görülmüștür. Büyük boyutlu numunelerin beton basınç dayanımlarının küçük boyutlu numunelere göre düşük çıkması, literatürüdeki önceki çalışmalar ve numunedeki kusur bulunma olasılığının artışı göz önünde bulundurulduğunda, beklenen bir sonuçtur. Silindir-küp basınç dayanımı dönüşüm katsayıları da göz önünde bulundurulduğunda, silindir basınç dayanımı ile küp basınç dayanımı arasındaki farkın, küçük boyutlu betonlarda daha fazla olduğu görülmektedir. Sonuç olarak ölçülen basınç dayanımı değerleriyle betonun basınç dayanımının numune boyutlarından etkilendiği ve bu etkinin daha çok yüksek dayanım düzeylerinde belirgin olduğu saptanmıştır.

Dolayısıyla, küçük boyutlu numunelerin basınç deneylerinde kullanılmasının artışı oldukça fazla avantaj sağlamasına karşın, dikkat edilmesi gereken bir önemli nokta da yüksek mukavemetli betonlarda küçük boyutlu numune kullanımı ile diğer boyuttaki numunelere oranla daha fazla etkiye maruz kalıyor olmasıdır. Diğer bir deyişle, yüksek dayanım sınıfında küçük boyutlu numuneler kullanıldığında, elde edilen dayanım sonuçlarının artmasıyla birlikte, numune boyutuna bağlı olan dayanım ilişkisindeki değişkenlik de artmaktadır. $\mathrm{Bu}$ nedenle de basınç dayanım testlerinde yüksek hassasiyetle ölçüm yapılması gerekmektedir. 
İ. Şanal / Beton Basınç Dayanım Testlerinde Küçük Ebatlı Küp Beton Numunelerin Yaygın Kullanımı İçin Şekil-Boyut Etkisinin Detaylı İncelenmesi

Sonuç olarak, küçük boyutlu numunelerin basınç dayanım sonuçlarında gerek şantiyelerde düşük kapasiteli basınç test makinası kullanımı, gerek azalan ağırlıkla birlikte numune taşıma kolaylığı ve gerek de zayi olan beton miktarının azaltılması bakımından, kalite denetiminde küçük boyutlu, $100 \mathrm{~mm}$ boyutunda küp numunelerin de kullanımında bir engel olmayip ( TS13515-T1 ve TS13515-T2) [16], ölçümlerde gerekli hassasiyet sağlandığında, pratikte kullanımının yaygınlaşması oldukça faydalı olacaktır.

\section{Teşekkür}

$\mathrm{Bu}$ çalışmanın gerçekleştirilmesinde destek ve yardımı oldukça fazla olan, OYAK Beton A.Ş., tüm çalışanları ve özellikle de Kalite Kontrol Bölümü'nden Sn. Armağan Sarıhan ve Sn. Deniz Sarıalioğlu'na sonsuz teşekkürlerimi sunarım.

\section{Kaynakça}

[1] Akçaözoğlu, K. "Silis Dumani İçeren Yüksek Dayanımlı Harçlarda Numune Boy Değișiminin Basinç Dayanımı ve Birim Kisalma Üzerindeki Etkisi", Doktora Tezi, Çukurova Üniversitesi, İnşaat Mühendisliği Anabilim Dali, 2007.

[2] Felekoğlu, B., Türkel, S., "Effects of Specimen Type And Dimensions on Compressive Strength of Concrete". Gazi Üniversitesi Fen Bilimleri Dergisi, 18 (4), S.639-645, 2005.

[3] Akakın, T. "Beton Numunesi Alma",TMH - Türkiye Mühendislik Haberleri, Sayi 427/5, 2003.

[4] Sümer, M., "Uçucu Kül Atıklarının Beton Üretiminde Değerlendirilmesi”, I. Ulusal İnşaat
\& Çevre Sempozyumu, Salihli, Bildiriler Kitabı, ss. 179-185, 1994.

[5] Li, B., Liang, W. and He, Z., "Study on High-Strength Composite Portland Cement with a Larger Amount of Industrial Wastes", Cement and Concrete Research, Vol. 32, pp. 1341-1344, 2002.

[6] Naik, T.R., Singh, S.S. and Ramme B.W. "Effect of Source of Fly Ash on Abrasion Resistance of Concrete", Journal of Materials in Civil Engineering, pp. 417-426, September-October 2002.

[7] Fu, X., Wang, Z., Tao, W., Yang, C., Hou, W., Dong, Y. and Wu, X., "Studies on Blended Cement with Large Amount of Fly Ash", Cement and Concrete Research, Vol. 32, pp. 1153-1159, 2002.

[8] Elkhadiri, I., Diouri, A., Boukhari A., Aride, J. and Puertas, F., "Mechanical Behaviour of Various Mortars Made by Combined Fly Ash and Limestone in Moroccan Portland Cement", Cement and Concrete Research, Vol. 32, pp. 1597-1603, 2002.

[9] Engin, Y. "Beton Silindir\&Küp Numune Basınç Dayanımı İliş̧kisi", www.betonvecimento.com, 2014.

[10] Elwell, J.D., Fu, G., "Compression Testing of Concrete: Cylinders vs. Cubes", Transportation Research and Development Bureu of Newyork, 1995.

[11] Erdoğan, T.Y. Beton. Odtü Geliştirme Vakfı Ve Yayıncılık A.Ş., Ankara, 2003.

[12] Özdemir, M., Numune Şekil Ve Boyutunun Yüksek Dayanımlı Betonun Basınç Mukavemetine 
İ. Şanal / Beton Basınç Dayanım Testlerinde Küçük Ebatlı Küp Beton Numunelerin Yaygın Kullanımı İçin Şekil-Boyut Etkisinin Detaylı İncelenmesi

Etkisi. Odtü Fen Bilimleri Enstitüsü, Yüksek Lisans Tezi, 1994.

[13] Çopuroğlu, O., Beton Numunesi Şekil Ve Boyutunun Basınç Ve Çekme Dayanımına Etkisi. Ege Üniversitesi Fen Bilimleri Enstitüsü, Yüksek Lisans Tezi, İzmir, 2001.

[14] TS EN 206, "Beton- Özellik, performans, imalat ve uygunluk standardı", 2014.
[15] TS EN 450-1 "Uçucu Kül - Betonda kullanılan - Bölüm 1: Tarif, özellikler ve uygunluk kriterleri", 2013.

[16] TS 13515, “TS EN 206-1'in Uygulamasına Yönelik Tamamlayıcı Standard", 2014.

[17] TS EN 12390, "Beton - Sertleşmiş beton deneyleri standardı", 2002. 